\title{
THE LEGALITY OF GOVERMENT ACTION IN AUDITING AND ASSESSING THE ACQUISITION VALUE OF ACQUISITION DUTY OF RIGHT ON LAND AND BUILDING IN SIDOARJO
}

\author{
Supriyanto \\ Study of Law Science and Development, Post-graduate School, \\ Airlangga University, Indonesia \\ E-mail: ayah10122007@yahoo.com
}

\begin{abstract}
The transfer of Customs Acquisition of Land and Building Rights from the central to the regional government based on Law \#28 of 2009 provides an opportunity for the regions to increase local revenues. BPHTB has great potential for local tax revenues because property growth in Sidoarjo Regency is quite large. To increase the acceptance of BPHTB referred to the Government of Sidoarjo Regency to conduct inspection and assessment of Tax Objects Value of BPHTB by re-regulating the Procedure of Collection of Acquisition Levy of Land and Building Rights in Sidoarjo Regent Regulation \#21 of 2017.
\end{abstract}

\section{KEY WORDS}

Authority, examination authority, revenue, land, buildings.

Increasing the efficiency and effectivity of goverment performances and public services, every regions have rights and obligationto manage and manintain their own administrations. While running their own goverment,every regionshave rights to have tax collectingon their resident. Tax will be funded based on the official regulations. The tax constitution has regulated in article 23A of The 1945 Constitution of the Republic Indonesia, it affirms that the placement of working load, such as tax and otherforcing charges has been arranged under The Constitution, therefore the tax collection should be complied The Constitution.

The background of Acquisition Duty of Right on Land and Building (BPHTB)are the social function of the land and building as one of the part of the nature resources,as well as its economical function for the owner,beside giving the access to fulfill basic human needs as a home and place for bussiness.

In the other words, for those whom have their right on the land or/and building, the obligation of giving some of their income for the country as a tax, known as BPHTB, paying needs to be fulfilled.

BPHTB is a tax colledted from the right on land and building. This tax firstly applied by Indonesia Goverment as the center of the tax in 1997 with the stipulation of The Constitution \#21 Year 1997 that has been revised and The Law \#20 of 2000. Based on the Article 12 Act. 4 and 5 of The Law \#33 of 2004 about Fiscal Balance berween central goverment and local goverment.

In the other words, all of the BPHTB income collected by the central goverment will be transferred to the local goverment with a revenue sharing fund mechanism, athough it will not be given to the contributor district/cityfully.

The basis of BPHTB is the income of the taxable object (NPOP), those are transaction value and market value, however in the practice it uses Sales Value of Taxable Object (NJOP) of Land and Building Tax. It happens because the recognition of selling and buying usually under NJOP, ene though it is corresponding with The Law \#12 of 1985, and emphasized by the Goverment Ordinance \#25 of 2002, the sales value for the NJOP is $20 \%$ up to $40 \%$ of the real values.

Based on the Article 3 of Goverment Ordinance \#55 of 2016 about The Mechanism of the tax collection and local retribution, among the 11 types of tax, only 3 types of tax that will be collected based on the stipulation of the District Head, those are Advertisement Tax, Groundwater Tax, and Land and Building Tax of Rural and Urban Area (PBB-P2). Even 
though, the tax cllection is stipulated by the District Head, Advertisement Tax and Groundwater Tax use Notice of Local Tax Assessment (SKPD). SKPD is an official letter that defines the value of the basic principle repayment on the tax. This sipulation is final, individual, and concrete in every process of its stipulation. The taxpayer has been involved on the process of the value calculation as the following the instructions.

Whereas PBB-P2 is an Notice of Land and Building Tax Payable (SPPT). It is a letter used to inform the value of the PBB-P2 that have to be paid by the taxpayer.

Giving the authorityon managing BPHTB to the District/City gives opportunities to set the value of BPHTB based on the Acquisition Value of Object (NPOP). NPOP is the transaction values and market values which are not only referring to the selling value of the object which is mentioned on the tax return (SPPT) PBB-P2.

In the same time, the transition of BPHTB and PBB-P2 become local taxes is not companied by the transition of the human resources of the appraisers in terms of appraising PBB-P2 in local District/City. This case appears because the appraisers handles PBB-P2 in the central goverment and has to change its authority to handle local PBB-P2. This case leads to the slowing down the PBB-P2 asaessment and data rejuvenation in Sidoarjo. In contrast, the activity of the citizen is dynamic as Sidoarjo is one of the pillar of Surabaya, Sidoarjo is the living place for the workers in Surabaya. The industrial, trading, and services growth and increasing population in Sidoarjo as the impact of urbanisationimpulses the demand of land while the amount of the land never grows. Technology, Interner has made the process of selling and buying land and building in Sidoarjo reach a wider ares, the buyer is not always from Sidoarjo but from other cities as well as other province. It may cause the diversity of value over the same object.

The transfer of land and building rights connected with 2 aspects, those are the transfer of the rights and the recepient of the rights. Both of them are faced with the provision of rights and obligations with respect to the transfer of rights. When the transfer has been received the income, in the Article 4 Act 2 The Law \#36 of 2008 about Income Taxes, the income received is taxable which is final.

The Income tax on the land and building transfer is regulated by The Goverment Ordinance \#34 of 2016 about Income Taxes by The Income of the Transfer Land and/or Building Rights, and Sales and Purchase Agreement of the Land and/or Building and its Changes. As an illustration the income of BPHTB in 2012 until 2015 is listed on the table below:

Table 1 - The realisation of the PBB-P2 and BPHTB revenue in Sidoarjo District compared to the PAD and Income (APBD) in 2011 until 2015

\begin{tabular}{|l|l|l|l|l|l|}
\hline Year & PBBP-2 (Rp.) & BPHTB (Rp.) & $\%$ & PAD & Income (APBD) \\
\hline 2011 & - & 91.429 .345 .870 & - & 484.313 .737 .307 & 2.005 .191 .397 .714 \\
\hline 2012 & 111.326 .978 .118 & 99.138 .455 .803 & 08,43 & 669.617 .556 .904 & 2.317 .444 .096 .384 \\
\hline 2013 & 147.187 .993 .871 & 155.400 .719 .381 & 56,75 & 858.433 .670 .217 & 2.618 .589 .423 .484 \\
\hline 2014 & 157.683 .880 .579 & 181.411 .980 .178 & 16,73 & 1.115 .332 .938 .500 & 3.273 .379 .955 .995 \\
\hline 2015 & 158.631 .832 .684 & 220.217 .563 .615 & 21,39 & 1.266 .786 .627 .409 & 3.556 .219 .038 .762 \\
\hline
\end{tabular}

Source: DPPKA Sidoarjo District.

Based on the data above, the growth of the BPHTB revenue from year to year increased compared to the previous year. The biggest positive growth happened in 2013, reach the of $56,75 \%$ from 2012 . This increase happened because in that year there was an adjustment NJOP PBB-P2.

Statement of The Problems. Based on the explaination on the background of study, there will be two problems that will be discussed:

- How do the authority of the auditing and determinationofthe acquisition value of taxable object BPHTB based on the regulation of the Head of Sidoarjo \#21 of 2017 about the process of collecting theAcquisition Duty of Right on Land and Building? 
- How are the mechanism of the taxable object's acquisition value on the Acquisition Duty of Right on Land and Buildingbased on the regulation of The Head of Sidoarjo \#21 of 2017 ?

The Purposes of the Study. In the background of the study there are a lot of explaination related to the tax collecting as well as the problems appear on the tax collection in Sidoarjo, in relation to them, there will be two purposes that are:

- To understand the authority of the Sidoarjo goverment in the auditing and determinationthe acquisition value of taxable object Acquisition Duty of Right on Land and Building based on the regulations of The Head of Sidoarjo \#21 of 2017;

- To reveal and analysed the mechanism of the auditing and determinationthe value of taxable object of Acquisition Duty of Right on Land and Building based on the Head of Sidoarjo regulation \#21 of 2017.

The Objectives of the Study. The result of the study is expected to give two objectivities that contains if the teritory and practice usage.

- From the teritory perspective, hopefully this study will help the stakeholder to arrage a regulation about auditing and stipulation the value of taxable object of of Acquisition Duty of Right on Land and Building.

- From the practice perspective, this study can give a new suggesstion on the process of maintaining the regulation and its implementation of the value taxable pbject of the of Acquisition Duty of Right on Land and Buildingthat encompass three aspects of the authority, procedure, and substance of the auditing. As the result the local govement's action has a validity.

References:

The Legality of the tax collection in legal system in Indonesia. Indonesia is a constitutional state, and the application of its concept in Indonesia is written in the country contitution, that is The 1945 Constitution of Republic Indonesia which is known as UUD NRI 1945. UUD NRI 1945 is a basic constitution of Indonesia that has the highest contitution in Indonesia's legal order.

The tax in UUD NRI 1945 is regulated in article 23A stating that Tax and other fund collection that compel for the country need is arraged in the Law.

Based on the article 1 \#1 UU \#6 of 1983, as the final enhanched by UU \#28 of 2007 about the Taxation General Provisions and TaxationRegulation is the obligatorycontribution for the country. This obligation is done by individual and compel. This regulation is based on the Law and wihout directreciprocal and will be used for the country needs to actualize the prosperity of the people.

The Requirements of Tax. To avoid any problems, Tax collection have to fulfill the following requirements:

- The tax collection have to be fair (terms of Justice);

- The tax regulation should based on the Constitution;

- The tax collection should not interfere any economic activity (terms of economic);

- The tax collection have to be efficient (terms of financial);

- The tax colection's regulaion should be simple.

The Legality of Goverment action. The scope of the legality in goverment's action thatcovers the authority, procedure, and substance. The auhority and substance are the base of formal legality. If one of those scope are not fulfilled, it leads to the juridical defects on the goverment's action. Judirical defects that will be appear will be on the authority, procedure, and substance. The Goverment's action should have a basis from the legal authority. The authority is gotten through three sources, that are attribution, delegation, and mandate.Atribution authority is usually given by dividing the authority in a country that has been regulated by The 1945 Constitution of Indonesia Republic or the Constitution, while the delegation and mandate authority are the authority that is delegated.

Those goverment regulatory and controling authority for people's lives will be limited by substance, for example the authority to determine the Land and Building Tax will be limited 
by the large of the land, the building, land classes, and building clasess but not concerning on the furniture of the house.

The Authority Based on the Administration Legal. Philips M. Hadjon states that there are three conceps of the authority as the public legal concept, that are influence, basic legality, and loga conformity. The influencing factor is the usage of the authority is for controlling the legal subject. This component's will wants every goverment or state officials action have a certain benchmarks or normal standart for any kind of authority that is based on the legal action.

The Sources of Authority. In the decisionsof administration legality there will be two ways to get goverment authority, that are attribution and delegation; sometimes mandate can be the source, which is placed as the other way to get the authority.An attribution points to the original authority on the basis of constitutional legality. While delegation emphasize on the delegating to a certain goverment agencies.

The Benchmarks of the Misusing Authority. In the legality administration concept, any given authority for the goverment agencies or the administration goverment officials always brings purposes and intentions. In the other words the application of the authority have to follow that purposes and intentions on the authority.

Legality principle is a basic guidance for the goverment's function to take actions in achieving golas. The given authority for the goverments is given through the Constitution.

A lot of situation in running the goverment function, the officials is facing any situation related to the Constitution that do not give any authority to take an action, in fact there is urgnt need for the goverment to take any action in reaching any goals. Freies Ermessen (diskresionare) is one of the facility that offer a sace for the officials or any atate administratives to take an action without being fullyattached to the Constitution.

Measuring the administrative officials' misused authority if there is an action that categorized as anafield action that has been measured with the given authority. Arbitrary authority (willekeur) is an action that is not based on the goverment legal reguation and public principle.

\section{METHODS OF RESEARCH}

Empirical normative is the method that will be used on this reseach. It is a merger of normative law and the addition of various empirical essesntials.

The approaches that is used in law research is statute approach, case approach, case approach, historical approach, comparative approach, and conceptual approach.The approach that is used is related to the legality of the goverment's action in Auditing and Determination of Object Acquisition Value of Tax on Land and Building Rights are: Statute approach; Conceptual approach.

The legal sources used in law researches can be distinguished into primary sources and secondary sources. The primary sources is an authoritative legal sources, means it has authority. The primary sources contains of The Constitution, legal notes or treatisein the making of the Law and the judge decision

Whereas, the secondary sources is a publication about law that is not legal documents. The publication contains of book, text, dictionary, law journal, and comment or judge decision.

Data or primary sources collected through interview, while secondary sources taken from literaturestudies, being inventoried, and taken from a relevant law issues. These secondar source collected through library research.

\section{RESULTS OF STUDY}

The authority of auditing and assessment NPOP BPHTB in Sidoarjo district:

The Legality of Authority in Investigating The Value of Taxable Object. Collecting the Acquisition Duty of Right on Land and/or Building (BPHTB) in Sidoarjo District is based on the Sidoarjo regulation \#5 of 2010, previously the tax is a central tax, but it is diverted into a local tax based on the Law \#28 of 2009 about local taxes and retributions.the Acquisition 
Duty of Right on Land and/or Building (BPHTB) is a kind of taxes which is collected by self assesment system. Based on Adrian Sutedi, the self assessment system in collecting taxes is a system of taxes collection that the tax payer determine by himself the amount of taxes based on the law of taxation.

The Legality of Authority in Invertigating and Assessment NPOP BPHTB. The basis of Legality in tax collection of Indonesia is regulated by the Amandemen of The 1945Constitution of Indonesia Republic of 1945 article 23A that states tax and other charges which are coercive for the country is regulated by the Law.

In the Law \#28 of 2009 about Local Taxes and Retributions, the Acquisition Duty of Right on Land and/or Building is regulated in the article 85 until article 93.

The goverment action is based on the norms of goverment's authority which is gotten from attribution, delegation, or mandate. Therefore, any goverment's action which is not based on the Law on giving any authority to take an action is an outrage action.

The authority on the auditing of local taxes, included BPHTB, is regulated on the Article 170 Act (1) Law \#28 of 2009 which states that the Head of the District has an authority to do auditing in testing the compliance fulfillment of local taxes and retributions obligations. This action is the sign that the goverment is implementing the law of local taxes and retributions.

The auditing authority of the Acquisition Duty of Right on Land and/or Building is regulated in Article 30 Act (1) and (3) of Local Regulation of Sidoarjo \#5 of 2010. It is in line with the authority of local taxes auditing as stated in the Article 170 of Law \#28 of 2009 as well as in Aritcle 28 of the Goverment Ordinance \#55 of 2016.

Based on the regulation in the Law and Local Regulation, it is clearly stated that the auditing authority on local taxes, including investigating BPHTB, is the authority of the Head of the District, and the furtherregulation about how to insvestigate, including who does the auditing wether it is The Head of the District or the others functionaries which is designated by the Head of the Distric, is regulated in the Regent's Regulation, while in the Goverment Ordinance \#55 of 2016 clearly states the Head of the District or the designated functionaries have the authority to investigate for the purpose of testing the compliance of local taxes obligations and to implement the Law.

The legality principle of the goverment's action is clearly stated about the exertion of the goverment administration is based on the legality, the principle of the human rights protection, and the general goverment principle on the Article 5 Law \#30 of 2014 about Goverment Administration. There are three principles aboutadministration law:

- Yuridikity principle (rechmatingheid), emphasizes the state administration can not being outrage.

- Legality principle (wetmatigingheid) states that every action of the state admininistration's functioners should have the basis law.

- Discretion principle (freises ermessen) is the freedom of the administrative officer to make a decision based on the self-opinions without contradicting with the legality principle.

The Legality of Procedure in Investigating and Assessment NPOP BPHTB. Taxes law is differenciate into formal taxes law and material taxes law. Formal taxes lawregulates the procedur to implement material taxes law, therefore in formal taxes law there is a regulation related to the process (the procedure of fulfillment of taxation rights and obligations).

The process of supervision on the suitability BPHBT payments is done through research of SSPD BPHTB payments, while the supervision of of the material truth which is done through field research or auditing on the payments, including SSPD BPHTB within 5 years since the tax arreas as it is regulated in the Regent of Sidoarjo Ordinance \#3 of 2011 about the procedure of the Acquisition Duty of Right on Land and Building.

The Local Tax notice that abbreviated to be SPTPD, is a notice which is used by the Tax Payer to report the tax calculation and/or payment, the tax and/or non-tax object, and/or assets and obligation based on the regulation of Local Tax Law. Based on the regulation, SSPD BPHTB is not only medium for the BPHT payments but also as the medium to do research on the assets and obligation. 
Based on the regulation, the research and auditing of the BPHTB payments is done afte the tax payers do its payments, after the signation of the transfer of rights deed by the notary public, minutes of auction by the Head of State Auction Office, and or after the transfer of rights deed being registered on the National Land Agency. If it happens because of owed tax already happens, accordingly the result of auditingafter getting the auditing result respond fro the tax payers will be appointed a notice of underpayment of local taxes, additional underpayment of local taxes, or zero assessment of local taxes, the amount of the principal tax will be charged by administrative payments in the amount of $2 \%$ (two percents) in a months that is counted from the taxes that are less paid or overtime for a maximum period of 24 (twenty four) months since the tax payable.

The Legality of the Audits Substance and The Assessment of NPOP BPHTB. The meaning of tax audits based on the Article 1 \#75 Law \#28 of 2009, Article 1 \#31 Goverment Law Numbet 55 of 2016, or Article 1 \#7 Local Goverment of Sidoarjo \#5 of 2010, is a series of activities that collect and process the data, informations, and/or evidence that has been done objectively and professionally based on a standart of Audit to test the compliance fulfillment of local tax obligations and/or for the other purpose of fullfillment the regulation of the Law of Local Taxes. While the meaning of research is regulated in the Goverment Ordinance \#55 of 2016 Article 1 \#29 that states Research is a series of activities which is done to assess the completeness filling notification letter and the attachments include an assessment of the truth on writing and calculating. Based on the regulation, the Audit has bigger portion compared to the research bcause it concerns on the data collection and cultivation, information and/or evidence.

In Article 87 Act (6), the same regulation also states that Acquisition Value of NonTaxable Object as it is states on the Act (4) and Act (5)is appointed by the Local Regulations.

The calculation of the Acquisition Value of Duty of Right on Land and Building is divided into 2 components that are land component and building component. The zone decisions or the market value is limited to the zone and market value on the land, while the assessment of the building beside on the condition, the development will be compared to the SPPT-PBB-P2, wether it will change, even become smaller on the building value, the decrease of the value or increase of the value.

The basic substance on the imposition of BPHTB is the value of the taxable object, on the buy and sell activity is based on the transaction value. The seller tax as well as the obligation of the repayment of PBB-P2 on the day of the transaction happen or the transfer of the land and building object is the obligation of the seller/the rights giver, and not the obligation of the buyer or recipient, but in reality the obligation is the responsibility of the buyer.

As one of the kinds of tax in District/City that is paid through the tax payer calculation, the result of the audit will be delivered to the tax payer through givinga letter of inspection results (SPHP), not a tax assessment, that the tax payer can give the respond of the audit result.

Taxable object of acquisition duty of right on land and building:

The Mechanism of theValue Audit of Txable Object PBHTB based on the Sidoarjo Regent Regulation \#21 of 2017. The Audit of NPOP BPHTB has been done in 2014. The resulf of the NPOP BPHTB research that do not mention the surface area, building area, NPOP TKP, the amount of the payable tax in accordance with the contents and the putposes, as it is intended in the Local Regulation or the Regents Regulation, including:

- The form audit and completeness of the applicant documents;

- The Audit of NPOP BPHTB;

- The respond of the audit result;

- The payments of BPHTB;

- The Audit of the BPHTB payment.

The implementation of Audit Mechanism in Acquisition Value of Acquisition Duty of Right on Land and Building:

- The Implementattion on the Tax Payer obliation or the authorixzation of tax payer to apply for audit. For the tax payer who fulfill the conditions, the audit team will deliver 
the value of the taxable object in accordance with the tax payer's explaination, so that the tax payer can do the payments as soon as possible without filed the respond ofthe audit result;

- Applicant Form of Audit and additional audit documents;

- Implementation of mechanism in certificate audit, application for the validationSSPD BPHTB and the audit of the BPHTB payment proof.

The implementation mechanism in the incompatible object compared to the regulation in SPPT PBB-P2:

- Implementation of the audit on some or partial transfer taxable object and the obligation of PBB-P2 repayments;

- Implementation of the audit NPOP TKP;

- The Audit on the gradualselling and buying;

- The Audit of taxable object selling in the housing as a raw material;

- The Audit on the addition of the tax payer name on the certificate;

- The Audit by the Audit Team;

- $\quad$ The Notice Letter Form of the Audit Result(SPHP) NPOP BPHTB.

\section{CONCLUSION}

From the explaination above, the conclusion that can be declared related to the legality of the goverment action on the Value Audit on the Obtaining Object of Tax on Acquisition Duty of Right on Land and Building in Sidoarjo are:

The Audit of the Obtaining Object of Tax on Acquisition Duty of Right on Land and Building and the Value Audit of the Aquisition Taxable Object based on the regent regulation \#21 of 2017 about the regulation of Collecting Acquisition Duty of Right on Land and Building as the replacement of Sidoarjo Regent \#3 of 2011 about the Regulation of Collecting the Acquisition Duty of Right on Land and Building adn the Regent Regulation \#42 of 2015 about the Value Audit of the Obtaining Object of Tax on Acquisition Duty of Right on Land and Building as it is changed with the Sidoarjo Regent Regulation \#55 of 2015, not only as an technique to increase the income of Acquisition Duty of Right on Land and Building, but also to have a legality not only for the Sidoarjo district goverment, the audit team NPOP BPHBT, but also for the tax payer and other institutions. The audit as it is regulated on the Sidoarjo Regent Regulation \#21 of 2017 is a bridge for gap problems between the Local Regulation of Sidoarjo \#5 of 2010 about the Acquisition Duty of Right on Land and Building, and the high community dynamic. Operational standart and precedure that mentioned in the Regent Regulations \#21 of 2017 has characteristics like generals, and have to further defined in the $\mathrm{n}$ the Decree of Head of Regional Tax Service Office of Sidoarjo that fulfill some principles in making of operational and procedure standart, that are easy and clear, efficient and effective, harmony, measurement, dynamic, oriented to the user or parties service, compliance and legal certainty.

The Goverment Regulation \#34 of 2016 about Income Tax on the Income from the Rights Transfer of Land and/or Building and the agreement of Shares and Sell pn the Land and/or Building, not only giving the easiness on paying the final PPh for the seller because of the decreasing value from $5 \%$ to $2,5 \%$ but also decreasing the will of controling land for the speculation purposeby the community that selling and buying the land and building for the commercials purpose, through not applying the rights of the land and building to avoid the tax obligation, this case in line with the Regent Regulation of Sidoarjo \#21 of 2017, because of the the sale and purchase agreement and the change is already owed the tax, for the seller and buyer. If the Final PPH payment obligation has been done by the seller, as it is regulated on the Goverment Ordinance \#34 of 2016, it will decrease the obligation of the buyer who will do the transfer of land and building right years after, at that time the buyer already has the money to sign the deed of sale and purchase and apply for the rights transfer to the National Land Agency, because the seller tax has been paid, as the result it is not the charge of the buyer or the increase of the seller tax. 
The forgery of the proof of payments Final PPh or BPHTB not only disadvantageous the local goverment, but also the tax payer, Notary Public, and National Land Agency. Inaccuracy and accuracy the audit officer happens because the validation is manual and has not been integrated in a system between the tax payer and the Notary Public/auction office, tax office, local tax office, and National Land Agency.

\section{SUGGESTIONS}

Based on the conclusion of the research, some suggestion will be delivered related to the goverment action inf auditing NPOP BPHTB in Sidoarjo, that are:

The Sidoarjo Regent Regulation \#21 of 2017 have to be followed up to establish the operational and procedure standart that will be established by the Head of Tax Ofice in Sidoarjo based on the inventory of the legal basis or the related Law, the connection of the Audit SOP NPOP BPHTB with SOP, warning, executor qualification, tools, and other equipments, also recording and data collection.

The need of sosialisation to the community that paying the tax can be done on the selling and buying transaction, the minimum of Final PPh is paid when the seller receives the money, wether it is full or partial payments, as the result the calculation of the seller's tax suitable with the amount of money that is received, not following the calculation of the amuount of buyer tax and not becoming a burden for the buyer in the future of the buyer will sign the dreed of sale and purchase or apply for the rights to the National Land Agency.

Need to synergybetween the institution in the tax collection and giving the service of the transfer of the rights of the land between the tax payer and Notary Public/StateWealth Service Office and Auction, Local Tax services agency, Pratama Tax Service Office, and National Land Agency to use an application that can be accessed together to ensure the legality of tax paying evidence, or to report PPAT because of the signation on the deed of shares and purchased.

\section{REFERENCES}

1. Ali Achmad, dkk, Menjelajahi Kajian Empiris terhadap Hukum, Kencana Prenadamedia Group, Jakarta 2013.

2. Hadjon, Philipus M, Pengantar Hukum Administrasi Negara, Gadjah Maa University Press, Yogyakarta, 2015.

3. Hamdi, Muchlis, Kebijakan Publik Proses, Analisis, dan Partisipasi, Ghalia Indonesia, Bogor, 2014.

4. Hamzah Andi, dkk, Dasar-Dasar Hukum Perumahan, PT Rineka Cipta, Jakarta, 2006.

5. Hartoyo Harry, dkk, Membedah Pengelolaan Administrasi PBB dan BPHTB, Mitra Wacana Media, Jakarta, 2010.

6. HR Ridwan, Hukum Administrasi Negara, PT Rajagrafindo Persada, Jakarta, 2016.

7. Latif, Hukum Administrasi Dalam Praktek Tindak Pidana Korupsi, Prenada Media, 2014.

8. Makhfatih Akhad, dkk, Pajak Daerah dan Retribusi Daerah, Metha Studio, Jakarta, 2010.

9. Mardiasmo, Perpajakan Edisi Terbaru 2016, Andi Offset Yogyakarta, 2016.

10. Marzuki, Peter Mahmud, Penelitian Hukum, Prenadamedia Group, Jakarta, 2005.

11. Parlindungn A.P, Pendaftaran Tanah di Indonesia, Bandung, Mandar Maju, 2009.

12. Sjahdeini ST. Remy, Hak Tanggungan, Jakarta, Penerbit Alumni, 1999.

13. Soeroso R, Perjanjian di Bawah Tangan, Jakarta, Sinar Grafika, 2010.

14. Suratman dan Dillah, Philips, Metode Penelitian Hukum, Bandung, Alfabeta, 2012.

15. Sutedi Adrian, Hukum Pajak, Jakarta Sinar Grafika, 2013.

16. Sutedi, Peralihan Hak atas Tanah dan Pendaftarannya, Jakarta Sinar Grafika, 2013.

17. Buku Saku Data Keuangan Kabupaten Sidoarjo Komparatif Tahun Anggaran 2011 s.d. 2015.

18. Rahman, Andi Muh. Ali, Hukum Administrasi negara dan Peradilan Tata Usaha Negara, judgeamar.blogspot.co.id/hukum-administrasi-negara-dan-peradilan.

19. The Fourth Amendment of 1945 Constitution of Republic of Indonesia. 
20. Law of 1960 about Agrarian Fundametal Law (State Gazette Of Indonesian Republic in 1960 \#104, additional State gazette of Indonesian Republic \#2043).

21. Law \#1 of 2011 about residence and (State Gazette of Indonesian Republic in 2011 \#7, additional State Gazette of Indonesian Republic \#5188).

22. Law \#20 of 2011 about Apartment (State Gazette of Indonesian Republic in 2011 \#108, additional State Gazette of Indonesian Republic \#5252).

23. Law \#23 of 2014 about Local Government (State Gazette of Indonesian Republic in 2014 \#244, additional State Gazette of Indonesian Republic \#5587).

24. Government Regulation \#48 of 1994 about Payment of Income Tax and Income from Transfer of Right to Land and / or Building (State Gazette of Indonesian Republic in 1994 \#77, additional State Gazette of Indonesian Republic \#4914).

25. Government Regulation \#40 of 1996 about Entrepreneur Use Right, Buildimh Use Right, and Use Right (State Gazette of Indonesian Republic in 1996 \#58, additional State Gazette of Indonesian Republic \#3643).

26. Government Regulation \#24 of 1997 about Land Registration (State Gazette of Indonesian Republic in 1997 \#59, additional State Gazette of Indonesian Republic \#3696).

27. Government Regulation \#34 of 2016 about Payment of Income Tax and Income from Transfer of Right to Land and / or Building, and Transaction Agreement Contract of Land/Building and its modification (State Gazette of Indonesian Republic in 2016 \#168, additional State Gazette of Indonesian Republic \#5916).

28. Government Regulation \#71 of 2008 about Third Amendment of Government Regulation \#48 of 1994 about Payment of Income Tax and Income from Transfer of Right to Land and / or Building (State Gazette of Indonesian Republic in 2008 \#164, additional State Gazette of Indonesian Republic \#4914).

29. Government Regulation \#55 of 2016 about General Procedure of Regional Tax Collection (State Gazette of Indonesian Republic in 2016 \#244, additional State Gazette of Indonesian Republic \#5950).

30. Government Regulation \#5 of 2010 about Custom Tax on Land and Building Right (Regional Gazette of Sidoarjo Regency in 2010 \#1 SERI B, additional Regional Gazette of Sidoarjo Regency \#14).

31. Government Regulation \#11 of 2011 about Village/City Land and Building Tax in 2011 \#5 SERI B, additional Regional Gazette of Sidoarjo Regency \#22).

32. Ministry of Apparatus Empowerment and Bureaucracy reformation Regulation \#35 of 2012 about Procedure of Standard Operational and Governance Administration Arrangement (Indonesian Republic State Gazette \#35).

33. Sidoarjo Regent Regulation \#3 of 2011 about Land and Building Right Custom Collection (Sidoarjo Regency Regional Gazette of 2011 \#3).

34. Sidoarjo Regent Regulation \#42 of 2015 about Land and Building Custom Inspection Value (Sidoarjo Regency Regional Gazette of 2015 \#42).

35. Sidoarjo Regent Regulation \#55 of 2015 about Amendment of Sidoarjo Regent regulation \#42 of 2015 about Land and Building Custom Inspection Value (Sidoarjo Regency Regional Gazette of 2015 \#55).

36. Sidoarjo Regent Regulation \#89 of 2016 about Position, Organization Structure, Duty, and Function of State Taxation Office Service (Sidoarjo Regency Regional Gazette of 2016 \#89).

37. Sidoarjo Regent Regulation \#21 of 2017 about Land and Building Custom Collection Procedure (Sidoarjo Regency Regional Gazette of 2015 \#55).

38. Ministry of general Employment and Public Housing decision \#552/KPTS/M/2015 about Maximum Housing Price Obtained By Credit of Modest House Ownership.

39. Ministry of general Employment and Public Housing decision \#552/KPTS/M/2016 about Limitation of Income Subsidized by KPR Target Group, Restriction of Simple House Sale Price of Tapan, and Unit of Prosperous Welfare, Seta of Housing Advance Subsidy.

40. SE Directorate General of taxation \#SE-55/PJ.6/1999 about Technical Procedure Analysis of NIR Determination. 